\title{
An enzyme preparation inactivating all penicillins and cephalosporins
}

\author{
PAMELA M. WATERWORTH \\ From the Department of Microbiology, University College Hospital, London
}

SUMMARY Commercial penicillinases vary in their capacity to destroy penicillinase-resistant penicillins and cephalosporins. A new freeze-dried preparation containing both beta-lactamase I and II was found to inactivate all penicillins and cephalosporins at levels above those likely to be encountered in clinical specimens.

The aminoglycoside antibiotics, particularly gentamicin, are increasingly widely used and frequently in patients with impaired renal function. All these drugs are potentially ototoxic and measurement of blood levels is often desirable but may be complicated by the presence of a second drug, most commonly a penicillin or cephalosporin. Assays of streptomycin in the presence of penicillin have been done for many years by the simple expedient of adding commercial penicillinase, and Newsome (1967) suggested that this might also inactivate cephaloridine, methicillin, and cloxacillin. However, it seems that not only different brands of penicillinase, but even different batches of the same manufacturer may vary in this respect (Garrod and O'Grady, 1971) and many workers have felt that it was unwise to rely upon any and have either used an organism known to be resistant to the second drug to assay the aminoglycoside or declined to attempt the assay.

Most commercial penicillinases are prepared from cultures of $B$. cereus or $B$. licheniformis which produce both beta-lactamase I which inactivates penicillin and ampicillin, and beta-lactamase II which inactivates the penicillinase-resistant penicillins and cephalosporins. The variability in the commercially available material is mainly due to the instability of beta-lactamase II, but the development by Sabath and Abraham (1966) of a zinc stabilized enzyme from $B$. cereus $569 \mathrm{H}$ opened up the possibility of the commercial production of a 'universal penicillinase' which could be relied upon to inactivate all the penicillins and cephalosporins in clinical use.

A freeze-dried preparation containing both beta-lactamases I and II, which is made from $B$. cereus $569 / \mathrm{H}$ by the procedure of $\mathrm{R}$. B. Davies and E. P. Abraham (unpublished), is now available from Received for publication 29 May 1973.
Whatman Biochemicals and the purpose of this paper is to recommend and describe its use in assays performed in clinical laboratories. For comparison, tests were also done with a 'cephalosporinase' prepared from Ent. cloacae as described by Stroy and Preston (1971) and kindly supplied by the Eli Lilly Company, and with Burroughs Wellcome penicillinase currently available in this department.

\section{Materials and Methods}

PENICILLINASES

Whatman beta-lactamase was supplied in bottles containing 50000 units to which $5 \mathrm{ml}$ sterile distilled water was added to give 10000 units $/ \mathrm{ml}$.

The cephalosporinase was received as a freezedried preparation of unstated potency and was reconstituted to give $1000 \mu \mathrm{g} / \mathrm{ml}$; it was used diluted $1 / 10(100 \mu \mathrm{g} / \mathrm{ml})$ in most experiments.

The penicillinase was diluted $1 / 5$ in sterile distilled water.

COMPARISON OF ACTIVITY IN CULTURE

MEDIUM

Doubled dilutions of each antibiotic were prepared in Oxoid nutrient broth no. 2 lightly inoculated with the Oxford Staph. aureus (approximately $10^{6}$ organism per $\mathrm{ml}$ ) and $1 \mathrm{ml}$ volumes were immediately added to tubes containing $0.02 \mathrm{ml}$ of each penicillinase. The cultures were examined for visible turbidity after overnight incubation at $37^{\circ} \mathrm{C}$.

INACTIVATION IN SERUM

Varying amounts of penicillins and cephalosporins were added to normal human serum and $0.5 \mathrm{ml}$ of each was added to $0 \cdot 1 \mathrm{ml}$ of the Whatman beta-lactamase or Lilly cephalosporinase. These mixtures were 
immediately placed in cups in plates seeded with $S$. lute $a$ and the presence or absence of any inhibition after overnight incubation at $37^{\circ} \mathrm{C}$ was noted.

\section{ASSAYS OF GENTAMICIN IN THE PRESENCE OF OTHER DRUGS}

Gentamicin was added to human serum to give 5 $\mu \mathrm{g} / \mathrm{ml}$ and varying amounts of the penicillins and cephalosporins were added to aliquots of this: $0.1 \mathrm{ml}$ of penicillinase was added to $0.5 \mathrm{ml}$ of these sera and the mixture immediately placed in cups in plates seeded with $B$. subtilis. These plates were incubated at $37^{\circ} \mathrm{C}$ overnight and the resulting zones were measured. These sera were also assayed by the vertical diffusion method of Mitchison and Spicer (1949) using Staph. aureus as the test organism.

Sera containing these mixtures of drugs were also assayed by the vertical diffusion method with varying amounts of the penicillinases added to the medium.

\section{ASSAYS ON CLINICAL SPECIMENS}

A number of specimens of blood and cerebrospinal fluid from patients receiving two drugs were assayed by the vertical diffusion method, adding the penicillinase either to the serum or to the medium.

\section{Results}

The marked difference between the activity of these three penicillinases is clear from the table. The Burroughs Wellcome penicillinase is highly effective against both penicillin and ampicillin but significantly less so against carbenicillin and has very little activity against cloxacillin and the cephalosporins.

In contrast, the Lilly cephalosporinase is highly active against the cephalosporins, has only a moderate effect on benzyl penicillin, and little or none on any other penicillin.

On the other hand the Whatman preparation is effective against all the eight drugs tested, though it

\begin{tabular}{lcrc}
\hline & $\begin{array}{l}\text { Burroughs } \\
\text { Wellcome }\end{array}$ & Lilly & Whatman \\
\hline Penicillin & 5000 & 500 & 10000 \\
Ampicillin & 1250 & 10 & 10000 \\
Carbenicillin & 40 & $<5$ & 10000 \\
Methicillin & 160 & $<5$ & 10000 \\
Cloxacillin & 1 & $<1$ & 1000 \\
Cephaloridine & $<1$ & 500 & 1000 \\
Cephalothin & 1 & 1000 & 500 \\
Cephalexin & $<1$ & 1000 & 125 \\
\hline
\end{tabular}

Table Highest concentration $(\mu \mathrm{g} / \mathrm{ml})$ of five penicillins and three cephalosporins permitting growth of the Oxford Staph. aureus when $0.02 \mathrm{ml}$ penicillinase is added to $1 \mathrm{ml}$ is apparent that cephalexin is the least readily destroyed.

The results of mixing the enzymes with varying concentrations of the eight antibiotics can be summarized by saying that when 1 part Whatman beta-lactamase was added to 5 parts of serum containing $100 \mu \mathrm{g} / \mathrm{ml}$ methicillin, cloxacillin, cephaloridine, cephalothin, or cephalexin or $1000 \mu \mathrm{g} / \mathrm{ml}$ carbenicillin; all were totally inactivated. In some early experiments when the enzyme was used at approximately one fifth of this strength, $64 \mu \mathrm{g} / \mathrm{ml}$ methicillin, cloxacillin, cephaloridine, and cephalothin were totally inactivated only by incubating the mixtures at $37^{\circ} \mathrm{C}$ for half an hour before placing them in the cups, but the same amount of cephalexin was not totally destroyed even after 24 hours' incubation. The addition of 1 part Lilly cephalosporinase to 5 parts serum produced immediate inactivation of $100 \mu \mathrm{g} / \mathrm{ml}$ of each cephalosporin but not of methicillin, cloxacillin, or $1000 \mu \mathrm{g} / \mathrm{ml}$ carbenicillin.

One of the advantages of the vertical diffusion method for assaying aminoglycosides is that all these antibiotics produce a band of enlarged colonies where growth starts at the bottom of the inhibition zone, but with all other antibiotics (except vancomycin) the colonies gradually increase in size giving no clear edge to the zone Thus if assays are done on sera containing more than one antibiotic, it is immediately apparent whether the zone of inhibition is produced by the aminoglycoside or by the second drug.

When 5 parts of serum containing $5 \mu \mathrm{g} / \mathrm{ml}$ gentamicin and $100 \mu \mathrm{g} / \mathrm{ml}$ methicillin, cloxacillin, cephaloridine, cephalothin, or cephalexin or 1000 $\mu \mathrm{g} / \mathrm{ml}$ carbenicillin were mixed with 1 part of Whatman beta-lactamase and immediately assayed by this method, all produced the typical band of large colonies bordering zones similar in size to those given by serum containing only gentamicin. When the Lilly cephalosporinase was added to these mixtures, only those containing cephaloridine, cephalothin, or cephalexin gave a characteristic gentamicin zone, the others all producing larger zones with no defined edge.

When assays are required on neonates or small children, the samples provided may be too small to be accurately diluted with penicillinase Another advantage of the vertical diffusion method is that not only can it be used with very small specimens, but also the volume of medium required is small (10 $\mathrm{ml}$ is sufficient for two or three assays) and it is thus possible to add the enzyme to the medium instead of to the serum.

When the sera containing the mixtures of antibiotics were assayed on medium containing 200 or 
500 units/ml Whatman beta-lactamase, the resulting zone of inhibition was produced by gentamicin in all except that containing cephalexin, which was not totally inactivated by either amount of enzyme. When 0.2 or $0.5 \mathrm{ml}$ Lilly cephalosporinase $100 \mu \mathrm{g} / \mathrm{ml}$ was added to the medium, the cephalosporins were all inactivated, but methicillin, cloxacillin, and carbenicillin were still present in all tubes.

Whatman beta-lactamase was added to sera from a number of patients receiving gentamicin and cloxacillin and/or carbenicillin and assayed by the vertical diffusion method and serum from neonates receiving gentamicin plus penicillin, cloxacillin, or carbenicillin was assayed by this method with the beta-lactamase added to the medium. In every case a typical gentamicin zone was obtained.

\section{Conclusions}

Whilst it is possible that different batches of Burroughs Wellcome penicillinase or stronger solutions of the Lilly cephalosporinase might have been more active than those tested here, it is clear that of these, only the Whatman beta-lactamase can be described as a 'universal penicillinase'. This is confirmed by an extensive study of a number of beta-lactamases recently reported by Newson and
Walsingham (1973). When 1 part of Whatman beta-lactamase was added to 5 parts of serum all the drugs tested were immediately inactivated at levels which will seldom if ever be encountered in clinical practice, and if excessively high levels are anticipated pre-incubation of the serum with the enzyme will make doubly sure that inactivation is complete. Alternatively, the addition of $0.2 \mathrm{ml}$ (2000 units) of is the enzyme solution to $10 \mathrm{ml}$ assay medium should be satisfactory for any of these drugs except possibly cephalexin; if the vertical diffusion method is used the nature of the zone edge will reveal any significant lack of inactivation.

\section{References}

Garrod, L. P., and O'Grady, F. (1971). Antibiotic and Chemotherapy, p. 483. Livingstone, Edinburgh.

Mitchison, D. A., and Spicer, C. C. (1949). A method of estimating streptomycin in serum and other body fluids by diffusion through agar enclosed in glass tubes. J. gen. Microbiol., 3, 184-203.

Newsom, S. W. B. (1967). Treatment of staphylococcal endocarditis. Brit. med. J., 3, 678 .

Newsom, S. W. B., and Walsingham, B. M. (1973). The use of $\beta$ lactamases in the clinical laboratory. J. med. Microbiol., 6, 59-66.

Sabath, L. D., and Abraham, E. P. (1966). Zinc as a cofactor for cephalosporinase from Bacillus cereus 569. Biochem. J., 98, $11 \mathrm{c}-13 \mathrm{c}$.

Stroy, S. A., and Preston, D. A. (1971). Specific assay of aminoglycosidic or polymyxin-type antibiotics present in human sera in combination with cephalosporins. Appl. Microbiol., 21, 10021006. 